E. Dubois in the early nineties of the last century of skeletal material in Java, to which he gave the title of Pithecanthropus erectus, there has been a division of opinion as to whether these remains were to be classified as human or anthropoid. Of recent years, opinion has tended in an increasing degree to incline to the latter; but recently doubt has been revived. Dr. E. Dubois, after prolonged study not only of the material known to anthropological text-books, the skull-cap, thigh bone and tooth from Trinil, but also of other material from the same provenance in his possession, for the most part not previously published, arrived at the conclusion, mainly on the evidence of the long bones, that we are here concerned with a gigantic gibbon. This conclusion, especially in view of the new material, has been received with respect, but not with general acceptance; and in the light of the new evidence it must be regarded as definitely disproved. Pithecanthropus now stands within the line of human descent, if only as a 'prehominid', a class in which Prof. Weidenreich would include him (or her) with Sinanthropus, Peking Man. It is interesting to note that Prof. Weidenreich's views as to the close relationship subsisting between Pithecanthropus and Sinanthropus are fully in accord with the recent conclusion of $\mathbf{P}$. Teilhard de Chardin, who on the palæontological evidence holds that the flora and fauna of China in the early Quaternary feriod were derived at least in part from the south.

\section{The National Fitness Campaign}

AT a reception given by the City Corporation at Guildhall, London, on February 17, in support of the activities of the National Fitness Council, H.M. the King, replying to the Lord Mayor's address of welcome, said that the cause for which they were meeting is one of the first importance, for while we are striving to bring the fruits of education within the reach of all, and to improve the conditions in which everyone may grow and live, we must remember that our bodies are the instruments with which we have to work, and that they, too, need education. In order to become physically fit, all must have the opportunity for regular exercise, and this is what the National Fitness Council and its Area Committees are concerned to promote, and it will be their object to secure facilities for everyone, young and old, to follow his or her own inclination in the method of taking this exercise. The good will and co-operation of all who may be in a position to help being vital to its success, the King warmly commended the movement to leaders of industry and commerce, employers and employed, and to local authorities. In conclusion, addressing youth in particular, His Majesty said, "The future will be in your keeping. The present is your opportunity to fit yourselves for a full, active and therefore happy, life. The decision is left to your free choice. It is for you to make the effort."

\section{British Industries Fair}

THE British Industries Fair, 1938, opened on February 21 and will remain open each day until
March 4 inclusive, except on Sunday, February 27. As in previous years, the Fair is divided between London and Birmingham. The London Section is held at Olympia and at Earls Court, the latter location taking the place of the White City, which was used last year and for many years before. Again it is to be noticed that only goods manufactured or produced mainly within the British Empire are permitted to be displayed. Among the trades exhibiting at Olympia we may note: chemicals (light and heavy), scientific instruments, photographic and cinematograph apparatus, radio apparatus and plastics, in addition to a large number of other industries usually classified as 'light' industries. At Earls Court, the main exhibits are those of the textile and furnishing trades and an Empire Section. Following the practice of previous years, the Engineering and Hardware Section is at Castle Bromwich, Birmingham. The exhibits here include farm and garden equipment, building materials and products connected with gas manufacture, utilization and distribution, electrical generation and transmission, transport and mining.

IT is interesting to notice that the total space occupied in London is more than $10,000 \mathrm{sq}$. ft. greater than that taken up for the 1937 Fair, and twenty of the trade sections exhibiting are larger than in 1937. At Birmingham, also, the area taken up by the exhibits is well in excess of the 1937 figure, which was a record. Some eight hundred exhibitors will be represented there, and it is stated that their stands are equivalent to a shop counter of British goods twenty-six miles in length. Holland, for the fourth year in succession, heads the list in the number of trade buyers who are visiting the Fair, Belgium being second, Germany third and France fourth. There is, of course, a large number of Empire buyers from overseas. In the Scientific and Optical Instruments Section at Olympia about twenty-six firms are exhibiting. This section of the Fair has grown considerably. Not many years ago, only a few firms exhibited and their stands were scattered indiscriminately. To-day this section occupies a prominent position in the main gangway, in which more than 5,500 sq. ft. are occupied in a combined display of all kinds of scientific apparatus. The instruments displayed include those used for research, medical, educational, industrial, and navigational (both marine and aerial) purposes. A review of the principal exhibits having scientific interest will be given in a future issue of NATURE.

\section{The Proposed Thames Barrage}

AT the meeting of the Metropolitan Water Board held on February 18 the report of the Works and Stores Committee on the proposal to construct a barrage across the River Thames at Woolwich came up for consideration. After relating the circumstances which have led to the institution of a public inquiry into the scheme by the Port of London Authority, the report pointed out that the Board's interests are materially involved in respect of the large filtration 
works adjoining the Thames at Barn Elms and Barnes where there are, in addition to primary filters at Barn Elms, 5 and $19 t$ acres respectively of slow sand filters from which a total of 27-31 million gallons a day of filtered water is obtained. The top water level of these filter beds varies from $11 \mathrm{ft}$. to $16 \mathrm{ft}$. above Ordnance datum, while the bottoms of the filters lie between $4 \mathrm{ft}$. and $9 \mathrm{ft}$. below the same datum. Were the water in the Thames to be permanently impounded, as contemplated in the scheme, the level of the ground water would be raised to a height substantially above the floor level of the filter beds, and these would accordingly stand in a body of polluted water, a condition for which they were not designed, and would be beset with risks of contamination to the filtered water. Another danger would be the increased external pressure against the structures during the periods of evacuation for cleaning. The report went on to show that the reception into the river of sewage and storm water laden with sedimentary matter of a putrefactive and infective character within the limits of the impounded area, would induce in the summer season insanitary conditions, resulting in demands for the release of increasing volumes of water over Teddington Weir in order to abate the nuisance, and that this would jeopardize the integrity of the Metropolitan supply at a time of high water consumption. The report concluded with a strong recommendation to offer strenuous opposition to the scheme.

\section{Galloway Hydro-electric Power Development}

AT the Institution of Civil Engineers on February 22, a series of papers was read dealing with the inception and execution of the undertaking belonging to the Galloway Water Power Co., situated in the south-west of Scotland and occupying the southerm portion of the mountainous region which lies between the estuaries of the Clyde and the Solway. The first paper by W. Hudson and J. K. Hunter gave an account of the initiatory stages and constructional details of the work. The area which has been developed includes the entire catchment (345 square miles) of the Galloway Dee, with, in addition, a further 50 square miles to the north-west, forming the catchment area of Loch Doon. With a slight exception, all the works lie on the greywacke formation, having a soft and shaly consistency. The climate is mild and the rainfall comparatively heavy, varying from 40 inches per annum on the coast to the south to more than 90 inches on the high ground between Loch Trool and Loch Doon. The more important works in their natural sequence consist of the Loch Doon storage reservoir, which provides main seasonal storage for the upper three power stations on the Dee, having an available capacity of 2,930 million $\mathrm{cu}$. $\mathrm{ft}$. and a total draw-down of $40 \mathrm{ft}$. The original level of the loch has been raised by $27 \mathrm{ft}$. Then come the Doon-Deugh tunnels by which water is drawn from the reservoir and discharged, as required, into the Dee. A series of three power stations have been installed at Kendoon, Carsfad and Earlstoun, normally operated together. A fourth station at
Glenlee with a reservoir at Clatteringshaws Loch, and a fifth station at Tongland complete the chain of development. The paper by $W$. Hawthorne and F. H. Williams described the mechanical and electrical plant, consisting of eleven main generating sets with outputs of $6,000-12,000$ kilowatts, the total rated capacity being 102,000 kilowatts and the voltage 11,000. The third paper, by $H$. W. Mountain, co-related the scheme with reference to the Grid, by which the bulk of the output is exported, half to central Scotland and half to north-west England. The total expenditure on the Galloway Development amounted approximately to $£ 3,000,000$ and the work was completed in the autumn of 1936 .

\section{Planning in a Democratic Government}

IN an article, "The Place of 'Planning' in a Demo. cratic Government", in the Nineteenth Century of December, Sir Daniel Hall discusses some of the reasons for the apparent inefficiency of democratic Government as compared with the efficiency of totalitarian States, and particularly with reference to the position of the technical expert in democratic administration. The problem of parliamentary Government, he suggests, is that of introducing planning into its administrative machinery to an extent which will permit a degree of foresight in the conduct of public affairs that will take long views, anticipate the effect of material progress on the social organism and concern itself with matters affecting the national welfare which have but little popular appeal. Sir Daniel Hall points out that the conception of planning has already entered our system to some extent, but our schemes are usually piecemeal and without provision for the consideration of their place in the national economy as a whole, while technical opinion is liable to be over-ruled and decisions determined less on intrinsic merits and informed criticism of proposals than by the volume of opposition aroused.

Sir Daniel Hall considers that it is on this question of expert advice and authority that the British administrative system is weakest, although in recent years successive Governments have come to recognize the need for technical advice and established such bodies as the Development Commission, the Department of Scientific and Industrial Research and the Medical Research Council. These bodies and par. ticularly the Economic Advisory Council provide the nucleus of an organization which could exercise the function of planning within the ordinary machinery of Government, and Sir Daniel Hall suggests that the Economic Advisory Council should be replaced by a Planning Council with a strengthened personnel and a technical staff, linked with the Research Councils. The Planning Council would remain an advisory body with the immediate function of advising the Cabinet or the departments on any question submitted to it. Its most important function, however, would be its initiative in planning, and its constitution would afford men eminent in the industrial, commercial, financial and scientific world opportunity of putting 